3. Nebes RD. Semantic memory in Alzheimer's disease. Psychol Bull 1989;106:377-394.

4. Tulving E. Episodic and semantic memory. In: Tulving E, Donaldson W, eds. Organization of memory. New York: Academic Press, 1972:381-403.

5. Heindel WC, Salmon DP, Shults CW, Walicke PA, Butters N. Neuropsychological evidence for multiple implicit memory systems: a comparison of Alzheimer's, Huntington's, and Parkinson's disease patients. J Neurosci 1989;9:582-587.

6. Simard M, van Reekum R. Memory assessment in studies of cognition-enhancing drugs for Alzheimer's disease. Drugs Aging 1999;14:197-230.

7. Keefe RSE, Silva SG, Perkins DO, Lieberman JA. The effects of atypical antipsychotic drugs on neurocognitive impairment in schizophrenia: a review and meta-analysis. Schizophr Bull 1999;25:201-222.

8. Green MF. What are the functional consequences of neurocognitive deficits in schizophrenia? Am J Psychiatry 1996;153: 321-330.

9. Goldman-Rakic PS, Selemon LD. Functional and anatomical aspects of prefrontal pathology in schizophrenia. Schizophr Bull 1997;23:437-458.

10. Schwartz BL, Hashtroudi S, Herting RL, Handerson $\mathrm{H}$, Deutsch SI. Glycine prodrug facilitates memory retrieval in humans. Neurology 1991;41:1341-1343.

11. Schwartz BL, Hashtroudi S, Herting RL, Schwartz BA, Deutsch SI. D-Cycloserine enhances implicit memory in $\mathrm{Alz}$ heimer patients. Neurology 1996;46:420-424.

\title{
Neuro/mages
}
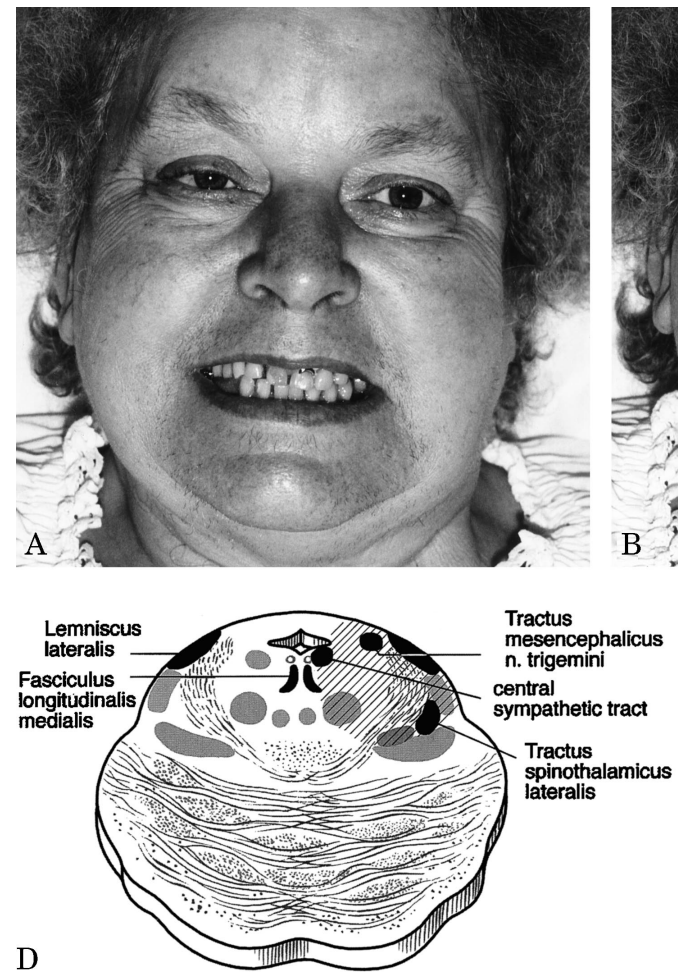
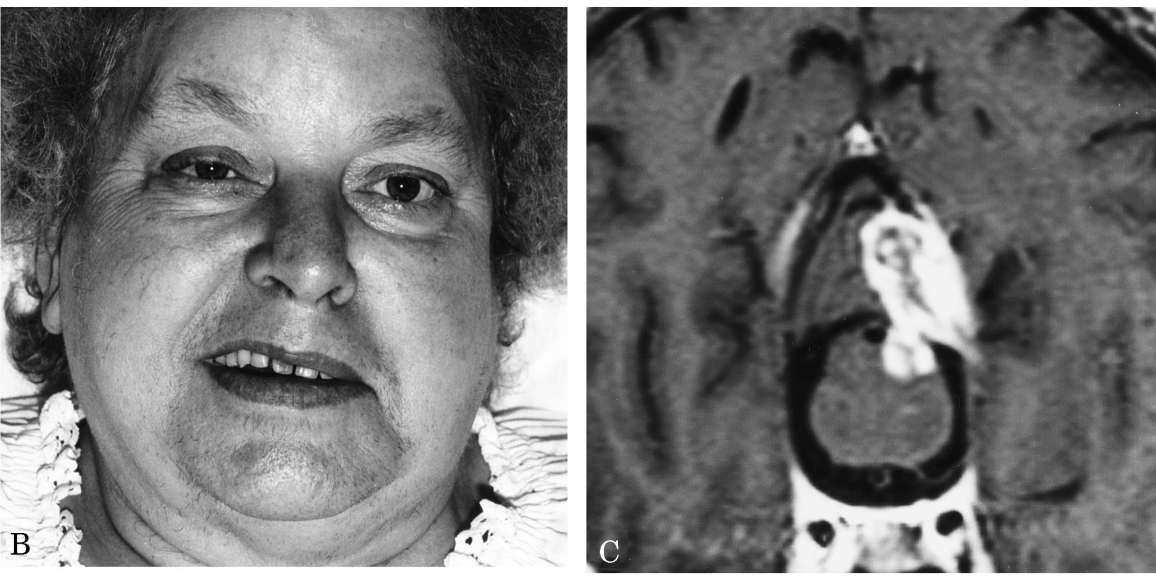

Figure. (A) "Showing the teeth" demonstrates symmetric innervation on volition. (B) Smiling discloses left emotional facial paresis. Right Horner's syndrome is demonstrated by the small palpebral fissure. (C) Contrastenhanced T1-weighted MRI. Section at the upper pontine level documenting involvement of the cerebellum and the right dorsal pontine tegmentum. For $C$ and $D$, right is on the right-hand side. (D) Drawing of the upper pontine level. The hatched area corresponds to the area involved as shown in $C$.

\section{Emotional facial paresis of pontine origin}

H.C. Hopf, MD, C. Fitzek, MD, J. Marx, MD, P.P. Urban, MD, F. Thömke, MD, Mainz, Germany

A 63-year-old patient noticed sudden ataxic stance and gait dysarthria. Transitory symptoms were vertigo, nausea, and horizontal diplopia. Examination showed central Horner's syndrome, impaired sweating of the face, hemiataxia, and moderate positional tremor on the right and facial paresis with emotional innervation only (figure, A and $\mathrm{B}$ ) and impaired pain and heat sensation over the entire hemiside on the left. Speech was dysarthric and hearing unimpaired. The masseter reflex amplitude was decreased by $<60 \%$ on the right. MRI showed infarction within the superior cerebellar artery (SCA) territory including the dorsolateral pontine tegmentum on the right (figure, C).

The "classic" signs of SCA infarction are ipsilateral limb and gait ataxia, static or intentional tremor, Horner's syndrome, and contralateral loss of pain and temperature sensation. Our patient represents the third well-documented description of contralateral emotional facial paresis (EFP) with SCA infarction. Two patients each had additional deafness (see reference 1) and Horner's syndrome and impaired sweating (our patient). ${ }^{1} \mathrm{EFP}$ results from pathology of the dorsolateral pontine area delineated by the sympathetic (Horner's) and spinothalamic tracts (sensory signs), the lateral lemniscus (deafness), and trigeminal mesencephalic tract/nucleus (masseter reflex) (figure, D). This area is quite distinct from the corticobulbar tract mediating voluntary facial innervation. ${ }^{2}$

1. Hopf HC, Müller-Forell W, Hopf NJ. Localization of emotional and volitional facial paresis. Neurology 1992;42:1918-1923.

2. Urban PP, Wicht S, Marx J, et al. Isolated voluntary facial paresis due to pontine ischemia. Neurology 1998;50:1859-1862. 


\title{
Neurology
}

\author{
Emotional facial paresis of pontine origin \\ Neurology 2000;54;1217 \\ DOI 10.1212/WNL.54.6.1217
}

This information is current as of March 28, 2000

\section{Updated Information \&} Services

Citations

Permissions \& Licensing

Reprints including high resolution figures, can be found at: http://n.neurology.org/content/54/6/1217.full

This article has been cited by 2 HighWire-hosted articles: http://n.neurology.org/content/54/6/1217.full\#\#otherarticles

Information about reproducing this article in parts (figures,tables) or in its entirety can be found online at:

http://www.neurology.org/about/about_the_journal\#permissions

Information about ordering reprints can be found online:

http://n.neurology.org/subscribers/advertise

Neurology ${ }^{\circledR}$ is the official journal of the American Academy of Neurology. Published continuously since 1951, it is now a weekly with 48 issues per year. Copyright . All rights reserved. Print ISSN: 0028-3878. Online ISSN: 1526-632X.

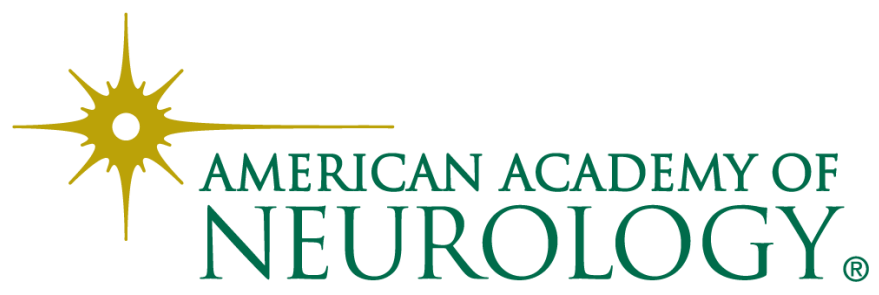

